\begin{tabular}{|l|l|l||}
\hline \multicolumn{2}{|c|}{ PublisherInfo } \\
\hline \hline PublisherName & $:$ & BioMed Central \\
\hline \hline PublisherLocation & $:$ & London \\
\hline \hline PublisherImprintName & $:$ & BioMed Central \\
\hline \hline
\end{tabular}

\title{
CD40 regulates rheumatoid factor production
}

\begin{tabular}{|l|l|l||}
\hline \multicolumn{2}{|c||}{ ArticleInfo } \\
\hline \hline ArticleID & $:$ & 41 \\
\hline \hline ArticleDOI & $:$ & $10.1186 /$ ar-1999-66745 \\
\hline \hline ArticleCitationID & $:$ & 66745 \\
\hline \hline ArticleSequenceNumber & $:$ & 37 \\
\hline \hline ArticleCategory & $:$ & Paper Report \\
\hline \hline ArticleFirstPage & $:$ & 1 \\
\hline \hline ArticleLastPage & $:$ & 3 \\
\hline \hline & $:$ & RegistrationDate : 1999-11-11 \\
ArticleHistory & $:$ & OnlineDate $\quad$ 1999-11-11 \\
\hline \hline ArticleCopyright & $:$ & Current Science Ltd1999 \\
\hline \hline ArticleGrants & $:$ & \\
\hline \hline ArticleContext & $:$ & 130752211 \\
\hline \hline
\end{tabular}




\section{Keywords}

B cells, CD40, rheumatoid arthritis, rheumatoid factors

\section{Context}

High affinity autoantibodies specific for the Fc regions of IgG are known as rheumatoid factors (RFs) and occur in the major of adults with rheumatoid arthritis (RA). The mechanisms behind the survival of these autoantibodies are not known, as it would be expected that cross-linking of Ig on the surface of a B cell would lead to anergy of deletion. Previous studies have, however, suggested that T cell help, delivered around the time of surface Ig cross-linking on B cells, leads to activation and secretion of higher affinity RFs. To identify the factor(s) required for the survival and differentiation of murine $\mathrm{B}$ cells transgenic for pathogenic high affinity human RF.

\section{Significant findings}

Mice transgenic for a human RF were generated. Injection with hIgG led to depletion of transgenic B cells in the spleen via apoptosis. The addition of allogeneic $\mathrm{T}$ cells resulted in both the survival of the transgenic cells and stimulation of RF production. IL-4, IL-15 and anti-CD40 signaling antibody protected transgenic cells from human IgG induced apoptosis in vitro. However, in vivo studies demonstrated that only CD40L blockade and not IL-4 or IL-15 inhibition could abrogate the effects of allogeneic T cells on RF transgenic B cell survival. Finally, using a T-cell-deficient human RF transgenic murine line, CD40 activation was shown to substitute for $\mathrm{T}$ cell help in both the rescue of transgenic cells and stimulation of RF production.

\section{Comments}

This study identifies the CD40 signal as being of central importance in the survival of RF B cells and, in the presence of IgG, leadingg to RF synthesis. The results suggest an autocrine loop in which the presence of CD40L and RF, both of which are found in the inflamed joint, results in the sustained synthesis of RF. It suggests that blockade of CD40 should lead to apoptosis of RF specific B cells in the 
rheumatoid joint and that manipulation of CD40L-CD40 signalling could be a useful therapeutic target in RA.

\section{Methods}

A transgenic murine line (AB29) expressing a rearranged, mutated, pathogenic human RF was used to determine the factors that modify the response of transgenic B cells to high doses of human (hIgG). To determine if soluble factors, rather than T cells, were required to rescue RF-transgenic B cells from hIgG mediated apoptotosis, a transgenic line (R29) was generated by repeated backcrossing of AB29 mice to the B6 RAG-/- line (B and T cell deficient).

\section{References}

1. Kyburz K, Corr M, Brinson DC, Von Damm A, Tighe H, Carson DA: Human rheumatoid factor production is dependent on CD40 signaling and autoantigen. J Immunol. 1999, 163: 3116-3122.

This PDF file was created after publication. 